\title{
Opieka w projekcie Wojciecha Prus Olszowskiego do Kodeksu Stanislawa Augusta
}

\author{
Fürsorge im Projekt von Wojciech Prus Olszowski \\ zum Gesetzbuch von Stanislaus August
}

1. Dotychczasowa literatura. 2. Projekty do kodyfikacji. 3. Obywatelski udział $\mathrm{w}$ pracach kodyfikacyjnych. 4. Autor Projektu ad codicem iudiciarium i jego dzieło. 5. Opieka według Projektu... 6. Wnioski.

1. Bisherige Literatur. 2. Kodifikationsvorschläge. 3. Bürgerbeteiligung an den Kodifikationsarbeiten. 4. Autor des Projekts ad codicem iudiciarium und sen Werk. 5. Fürsorge nach dem Projekt... 6. Schlussfolgerungen.

1. W nauce polskiej, problematyce opieki w projektach do Kodeksu Stanisława Augusta więcej miejsca poświęciło dotychczas jedynie trzech autorów ${ }^{1}$. Przemysław Dąbkowski na marginesie pracy Prawo prywatne polskie ${ }^{2}$ wskazał na projekt pióra ks. Andrzeja Reptowskiego. Janina Kelles-Krauzówna ${ }^{3}$ omówila i wydała drukiem cztery prospekty: ks. Hieronima Wyszomirskiego, ks. Andrzeja Reptowskiego w dwóch wersjach oraz dwa anonimowe projekty znajdujące się w zbiorach Biblioteki Czartoryskich w Krakowie. Trzeci z autorów - Stanisław Borowski ${ }^{4}$, publikując materiały do Kodeksu Stanislawa Augusta zamieścił wśród nich dwa projekty dotyczące opieki: ks. H. Wyszomirskiego oraz ks. A. Reptowskiego w wersji poszerzonej w stosunku do prospektów przedstawionych przez J. Kelles-Krauzównę.

\footnotetext{
'Ponadto jedną stronę poświęcił instytucji opieki w projektach do Kodeksu Stanisława Augusta I. J a k u bow sk i, Prawo rzymskie w projektach kodyfikacyjnych polskiego Oświecenia, Acla Universitatis Lodziensis 1984, Folia iuridica, nr 15, s. 103.

${ }^{2}$ P. Dąbkowski, Prawo prywatne polskie, t. I-II, Lwów 1910-1911.

J. Kelles-K rauzówna, Opieka nad maloletnimi sierotami w projektach do „Kodeksu Stanislawa Augusta", Roczniki Zakładu Narodowego im. Ossolińskich, Lwów 1927.

${ }^{*}$ S. B or owsk i, Kodeks Stanislawa Augusta. Zbiór dokumentów, Warszawa 1938, s. 140-154.
} 
2. W związku $\mathrm{z}$ monograficznym opracowaniem J. Kelles-Krauzówny, kwestią otwartą pozostaje problem, czy rzeczywiście dwa anonimowe projekty opublikowane przez tę autorkę uznać można za materiały do Kodeksu Stanisława Augusta.

S. Borowski wskazal, iz prospekty te dotyczą Zbioru Praw Andrzeja Zamoyskiego ${ }^{3}$. Niejasna argumentacja na poparcie powyższego wywodu spowodowała, iż projekty te nadal klasyfikowane są $w$ literaturze jako prospekty, nadesłane $w$ ramach konkursu ogloszonego przez deputacje, do napisania nowego kodeksu praw cywilnych i kryminalnych doby Sejmu Czteroletniego ${ }^{6}$. Porównanie tekstu opublikowanego przez J. Kelles-Krauzównę jako projektu II, którego autorstwo przypisała Józefowi Wybickiemu ${ }^{7}$, z fragmentem rękopisu znajdującego się w Bibliotece Kórnickiej, będącym przedostatnią wersją redakcji Zbioru Praw Zamoyskiego opatrzoną glosami Krzysztofa Hilarego Szembeka ${ }^{8}$, potwierdza tezę Borowskiego.

Oba teksty dotyczące opieki posiadają tyleż samo paragrafów oraz są identyczne $w$ treści $\mathrm{z}$ wyjątkiem: $\S 28$ anonimowego projektu, którego to paragrafu brakuje w rękopisie kórnickim, oraz dodanego w wersji kórnickiej $\S 58^{9}$ nieznanego wersji publikowanej przez Kelles-Krauzównę.

Dodatkowym argumentem przemawiającym za przynależnością projektu Wybickiego do Zbioru Praw Sądowych jest zdanie znajdujące się na początku prospektu: Obserwacje na ten artykul podane no. 24 na końcú ${ }^{10}$. Technika prac kodyfikacyjnych polegająca na opatrywaniu poszczególnych redakcji zbioru glosami i obserwacjami charakterystyczna była dla zespołu Andrzeja Zamoyskiego, gdzie prace tego typu wykonywali Michał Węgrzecki i Krzysztof Hilary Szembek ${ }^{11}$. Deputacja kodyfikacyjna czasów Sejmu Czteroletniego pracowała w ramach subdeputacji. Poszczególni jej członkowie przedstawiali projekty własnego autorstwa na posiedzeniach całego zespołu, podczas których po dyskusji, ewentualnie zlecano samemu autorowi lub innym osobom poprawienie projektu. J. Wybicki, zasiadający $w$ deputacji koronnej do ułożenia nowego kodeksu, był obecny na sesji 16 . W dniu 7 stycznia 1792 r., kiedy czytany był projekt o opiece pióra ks. A. Reptowskiego, mógł więc ewentualne uwagi zglosić na zebraniu deputacji.

\footnotetext{
${ }^{5}$ Ibidem, s. IX.

"Patrz: E. B orkowska-Bagi eńska, „Zbiör Praw Sqdowych" Andrzeja Zamoyskiego, Poznań 1986, s. 185.

' J. K elles-K r a u zówna, Opieka..., s. 34-49.

"Rkps BK [Biblioteka Kórnicka] 1097, k. 254 i n.

Ibidem, k. 276 v i 277.

${ }^{10}$ Rkps. Biblioteka Czartoryskich, sygn. 1433, s. 509.

1 Patrz: E. B ork owska-Ba gi én ska, ,Zbior..., s. 88-92 oraz „Poczqtki najpierwsze do prawodawstwa". Materialy z prac nad Zbiorem Praw Sadowych Andrzeja Zamoyskiego, CPH 1986 , t. XXXVIII, z. 2, s. 119-122.
} 
Tekst zamieszony przez J. Kelles-Krauzównę jako projekt III $^{12}$, podobnie jak projekt II zawarty $w$ alegatach do prac deputacji, z pewnością również odnosi się do Zbioru Praw Sądowych. Wykazuje duże podobieństwo w treści do projektu J. Wybickiego, być może stanowi jedną z wersji tego prospektu. Ustalenie autorstwa niniejszego projektu jest trudne, ponieważ - $w$ świetle znanych źródeł - niemożliwe jest określenie wkładu poszczególnych członków zespołu Andrzeja Zamoyskiego w dzieło układania Zbioru Praw. Kluczem do ostatecznego rozstrzygnięcia kwestii przynależności anonimowych projektów do próby kodyfikacji prawa w roku 1776 czy 1791 byłoby z pewnością przeanalizowanie materiałów znajdujących się w zbiorach Chreptowiczów w Szczorsach. Wywiezione w 1915 r. do Moskwy archiwum szczorsowskie, obecnie w znacznej części znajduje się Bibliotece Ukraińskiej Akademii Nauk w Kijowie (podobnie jak biblioteka). Korespondencja Chreptowiczów znajduje się w Petersburgu. Materialy te być może powrócą wkrótce do Szczors, gdyż władze białoruskie juz podjęły starania $w$ celu ich odzyskania ${ }^{13}$.

3. Pomimo świadomości istnienia większej liczby źródel dotyczących Kodeksu Stanisława Augusta nie udało się dotrzeć S. Borowskiemu do wszystkich materiałów. Wśród sporządzonego przez niego spisu poszukiwanych tekstów znajduje się wzmianka o Projekcie ad codicem iudiciarium wydanym przez obywatela województwa sandomierskiego ${ }^{14}$. Informacja o tym projekcie pochodzi z ogłoszenia o jego sprzedaży zamieszczonego w „Gazecie Narodowej i Obcej"'s. S. Borowski poddal jednak w wątpliwość możliwość jego publikacji $z$ uwagi na brak choćby jednego egzemplarza tejże pracy. Druk ów udalo się odnaleźć w 60 lat później Józefowi Szczepańcowi w związku $\mathrm{z}$ badaniami nad dziejami Drukarni Wolnej Jana Potockiego ${ }^{16}$.

Niniejszy artykul stanowi próbę omówienia Projektu ad codicem iudiciarium $^{17}$, autorstwa - jak wskazuje strona tytułowa - Wojciecha Prus Olszowskiego, w zakresie przepisów dotyczących opicki.

12 J. Kelles-Krauzówna, Opieka..., s. 49-53.

${ }^{13}$ Odnośnie do Biblioteki Chreptowiczów patrz: S. P t a s z y cki, Krótka wiadomość o rękopisach biblioteki Szczorsowskiej (z ziemi pagórków leśnych, z ziemi lakk zielonych), Warszawa 1899; P. Bańk owski, Dwa polskie archiwa Ukrainskiej Akademii Nauk, Archeion 1964, t. XL, s. 191-199; E. R abowicz, Polonica oświeceniowe w ZSRR, Archiwum Literackie 1960, t. 5, s. 558-561. Pobyt i kwerenda przeprowadzona przeze mnie w Bibliotece Ukraińskiej Akademii Nauk nie przyniosły odpowiedzi na powyższy problem. Odnośnie do restytucji biblioteki patrz: M. A. Koprowski, Mickiewicz wraca do Szczors, http://www.goscniedzielny.pl/Archiwum/nr30/13.

${ }^{14} \mathrm{~S}$. B or ow sk i, Kodeks..., s. XIV. Wzmianke o tym uczynił wcześniej A. Win ia r z, Kwart. Hist. 1893, t. VII, s. 135.

1) Gazeta Narodowa i Obca, 4 IV 1792, nr 27, s. 162.

$16 \mathrm{~J}$. S z czepaniec, Drukarnia wolna Jana Potockiego w Warszawie 1788-1792, Wrockaw 1988 , s. $59-60$ i $213-214$.

"Jedyny egzemplarz tego druku znajduje się w zbiorach Biblioteki Jagiellońskiej pod sygn. BJ 221724-III. 
4. Wybór członków dwóch deputacji - koronnej i litewskiej - 29 czerwca $1791 \mathrm{r}^{18}$ nie pozbawił obywateli możliwości włączenia się w dzieło kodyfikacji prawa. Nowo wybrane deputacje dobierały do swego skladu, zgodnie $\mathrm{z}$ uchwałą sejmową ${ }^{19}$, także inne osoby (biorąc przy tym pod uwage przede wszystkim praktykę prawniczą) $)^{20}$. Szeroki udzial obywateli w pracach nad reformą prawa umożliwil, przyjęty na forum sejmowym, pomysł ks. Hugona Kolłątaja oraz Ignacego Potockiego ${ }^{21}$ ogłoszenia konkursu na napisanie i przesłanie do deputacji projektu całości lub części nowego kodeksu. Dodatkową zachętą dla piszących miała być nagroda $w$ wysokości 20 tys. złotych polskich ${ }^{22}$, co było równowartością połowy rocznego uposażenia hetmana polnego koronnego ${ }^{23}$.

O tym, jak dużą wagę przywiązywali posłowie do rozpisania konkursu, świadczy fakt, iż marszałkowie konfederacji byli zobligowani przez Sejm do wydania uniwersałów mających zachęcić obywateli do podawania myśli, zdań $i$ projektów, stosownie do zapadlego prawa ${ }^{24}$. Deputacje miały rozpocząć pracę od napisania odezwy i prospektu, według którego pisane miały być prace konkursowe. Nie znaczyło to jednak, by obywatele byli zobowiązani do przyjęcia propozycji deputacji dotyczących ogólnego podziału materii i uwzględnienia zbioru zasad ogólnych, nakreślonych do poszczególnych rozdziałów przez członków zespołu kodyfikacyjnego. $\mathrm{Z}$ zachowanego rękopisu

${ }^{18}$ Patrz: Uchwala sesji Prowincji Koronnych z dnia 29 VI 1791 r. w sprawie deputacji kodeksavej. Analogicznie dla Wielkiego Księstwa Litewskiego - S. B or owski, Kodeks..., s. 21-23.

19 S. B or ow sk i, Kodeks..., s. 22-23.

${ }^{20} \mathrm{~W}$ drodze kooptacji zasiadły w deputacji koronnej osoby, które następnie aktywnie brały udział w jej pracach: Grzegorz Piramowicz, Walerian Bogdanowicz, Franciszek Barss, Stanisław Baczyński, Cyprian Sowiński, Tomasz Czech. Wkładu w prace kodyfikacyjne pozostałych czterech członków wybranych przez deputację (Scipona Piattolego, Teodora Ostrowskiego, Józefa Koblańskiego i Chrząszczewskiego) nie udało się dotychczas ustalić.

${ }^{21}$ Patrz: Mowa Hugona Kollataja na sesji sejmowej dnia 28 VI 1791 r. - S. B orowski, Kodeks..., s. 18. Hugo Kołłątaj domagał się ogłaszania publicznych konkursów w ważniejszych materiach w Listach Anonima - H. Kołłąt a j, Listy Anonima i prawo polityczne narodu polskiego, t. II, opr. B. Leśnodorski i H. Wereszyck a, Warszawa 1954, s. 116. Także Seweryn Potocki, przedstawiając na forum sejmowym dnia 28 XII 1789 r. projekt powołania deputacji dla przeprowadzenia zmian $w$ ordynacji trybunałów $\mathrm{i}$ innych sądów, wskazał na konieczność brania pod uwage przez kodyfikatorów myśli przesłanych do deputacji przez pozostalych po domach troskliwych o dobro krajów obywatelów - W. S z a f r ań ski, Nieznane materialy do tzw. Kodeksu Stanislawa Augusta, CPH 2000, t. LII, z. 1-2, s. 256.

22 Patrz: Oznaczenie deputacji do napisania codicis civilis et criminalis dla Prowincji Koronnych zapadlego oraz analogicznie dla Wielkiego Księstwa Litewskiego - S. B o r o w ski, Kodeks..., s. 20.

${ }^{23}$ Patrz: Etat Wojska Obojga Narodów - uchwała sejmowa z dnia 8 X 1789 r., VL, t. IX, s. 112.

${ }^{24}$ Patrz: Uchwala sesji Prowincji Koronnych $z$ dnia 29 VI 1791 r. w sprawie deputacji kodeksowej. Analogicznie dla Wielkiego Księstwa Litewskiego - S. B or ow ski, Kodeks..., s. 22-23. 
Myśli do odezwy deputacji autorstwa Grzegorza Piramowicza i Franciszka Ksawerego Dmochowskiego ${ }^{25}$, poprawionego przez ks. Hugona Kołłątaja i zawierającego wskazówki dla podejmujących się pisania księgi praw cywilnych i kryminalnych oraz sposobu dzialania zespołu kodyfikacyjnego, można wnioskować, iż wszelkie prace deputacji miały być podporządkowane ułożeniu prospektu konkursowego, nie zaś napisaniu przez deputację całości projektu nowego kodeksu i przedstawieniu go Sejmowi celem uchwalenia ${ }^{26}$. Deputacja zapewne nigdy nie skończyla prac nad prospektem i nie wydała go wraz $z$ odezwą drukiem ${ }^{27}$. Stanęly temu na przeszkodzie: najpierw zlecenie przez Sejm opracowania projektów prawa o sądach ziemiańskich $i$ trybunalskich ${ }^{28}$, następnie zaś wybuch wojny polsko-rosyjskiej w maju $1792 \mathrm{r}^{29}$

Brak publicznego ogloszenia odezwy wraz z prospektem nie spowodował zahamowania nadsyłania prac przez obywateli $w$ ramach konkursu ogloszonego 28 czerwca $1791 \mathrm{r}$. W świetle znanych materiałów, spośród projektów konkursowych $^{30}$ jedynie dzieło Wojciecha Olszowskiego stanowiło próbę calościowego uregulowania materii kodeksowej.

5. O autorze Projektu ad codicem iudiciarium wiadomo niewiele. Na podstawie wskazówek zamieszczonych na pierwszej stronie prospektu: imienia, nazwiska, klejnotu rodowego - Prus oraz miejsca pochodzenia - województwo sandomierskie, udało się ustalić, iż Wojciech Olszowski pieczętujący się herbem Prus II pochodzil $z$ sieradzkiej linii tego domu. Był synem Stanisława

${ }^{25}$ S. Borowski, Kodeks..., s. 66-74.

${ }^{26}$ Podobnie: A. Winiarz, KH 1893, t. Vll, s. 132, oraz A. Ohanowicz, Z. Radwański, Ostatnia próba kodyfikacji prawa cywilnego w Rzeczypospolitej szlacheckiej (Kodeks Stanislawa Augusta), PiP 1952, z. 11, s. 670. Odmiennie E. K r zy mu s k i, Józef Szymanowski. Przyczynek do reformy prawa $i$ procesu karnego w Polsce $w$ końcu XVIII w., Biblioteka Warszawska 1891 , t. IV, z. 2, s. $448-450$.

${ }^{27}$ A. Ohanowicz, Z. R adwański, Ostatnia..., s. 669-670.

${ }^{28}$ Deputacja pracowała na tymi projektami od $19 \times 1791$ r. do 4 I 1792 r.

${ }^{29}$ Ostania - 26 sesja deputacji koronnej odbyła się 17 III 1792 r.

${ }^{30} \mathrm{Z}$ materiałów przesłanych $\mathrm{w}$ ramach konkursu za projekty w ścisłym tego słowa maczeniu uznac można jedynie prace: ks. Wyszomirskiego, Gabriela Taszyckiego, Wojciecha Wolskiego, pióra anonima Uwagi o prawach majqtkowych, autora nieznanego Projekt podzialu Kodeksu Stanislawa Augusta. Dzieła Grzegorza Suchowolskiego, o którego istnieniu świadczy jego list przesłany do deputacji 8 III 1792 r., nie udało się odnaleźć. Trzy pozostałe szkice: Bonifacego Garyckiego, autora bezimiennego Myśli ogólne o kodeksie oraz list „Województw wielkopolskich obywatela" do Hugona Kołłątaja z 23 XI 1791 r. - to raczej uwagi niż projekty. Z wyjątkiem anonimowego Projektu podzialu Kodeksu Stanislawa Augusta opublikowanego przez A. Lityńskiego (Nieznane materialy do projektu Kodeksu Stanisiawa Augusta, CPH 1978, T. XXX, z. 2 s. 234-244), wszystkie podane powyżej materiały opublikowai S. B or ow ski, Kodeks..., s. 147-154, 96-111, 199-204, 112-113, 31, 91-95, 45-48, 27-3i. 
i Marjanny z domu Osuchowskiej. Żonaty z Marjanną Opalińską, miał $z$ nią syna Wincentego - późniejszego rejenta powiatu orłowskiego ${ }^{31}$.

Wojciech Olszowski - jak się wydaje - nie pełnił w Pierwszej Rzeczypospolitej żadnej funkcji urzędniczej $\mathrm{w}$ swoim województwie, za wyjątkiem krótkotrwałego piastowania urzędu komisarza wiślickiego $(1792 \mathrm{r} \text {. })^{32}$. Był dziedzicem Woli Goryńskiej - majątku położonego w powiecie radomskim, niedaleko Gorynia. Technika redakcji przepisów we własnym projekcie świadczy o tym, że albo był prawnikiem, albo osobą blisko $\mathrm{z}$ prawem związaną. Prospekt jego autorstwa musial powstać na przełomie 1791 i 1792 r. ${ }^{33}$ Wydrukowany został w Drukarni Wolnej Jana Potockiego przed data 4 kwietnia 1792 r., w tym bowiem dniu "Gazeta Narodowa i Obca" już informowała czytelników o moźliwości zakupu tego dzieła.

Projekt adresowany do Deputacji Konstytucyjnej, zwanej też sejmową, być może trafił do niej za pośrednictwem Michała Strasza - posła sandomierskiego, podsędka radomskiego ${ }^{34}$, wybranego do tejże deputacji w maju $1791 \mathrm{r}^{35}$ Pochodzil on podobnie jak Wojciech Olszowski z powiatu radomskiego.

Projekt ad codicem iudiciarium składa się $\mathrm{z}$ inwokacji oraz 51 paragrafów opatrzonych tytułami i podzielonych na punkty ${ }^{36}$. Chociaż Olszowski nie dokonał podziału swojego prospektu na księgi, to analiza przepisów pozwala na wyróżnienie czterech jego części: pierwszej - dotyczącej opisania sprawiedliwości w pierwszej instancji, drugiej - będącej powiązaniem przepisów dotyczących statusu spolecznego z przepisami cywilnoprawnymi, trzeciej - obejmującej prawa kryminalne, oraz czwartej - opisującej odwołania i trybunaty ${ }^{37}$.

${ }^{31}$ Rodzina. Herbarz szlachty polskiej, opr. S. Uru ski, t. XII, Warszawa 1912, s. 331-332.

${ }^{32}$ Rkps Ossolineum 1778/III, s. 607-613. Wątpliwość co do piastowania przez Olszowskiego innych urzędów powstaje $z$ uwagi na zniszczenie podczas II wojny światowej ksiąg grodzkich i ziemskich województwa sandomierskiego. W spisie urzędników tegoż województwa, wydanym przez Bibliotekę Kórnicką, brak wzmianki o Wojciechu Olszowskim - Urzędnicy województwa sandomierskiego XVI-XVIII wieku, opr. K. Chła p ow ski, A. F a In i ow sk a- Gradowska, Kórnik 1993.

${ }^{33} \mathrm{~W}$ projekcie Wojciecha Olszowskiego znajduje się obszerny fragment dotyczący sądów ziemiańskich i trybunałów, w treści odmienny od uchwalonego 10 I 1792 r. prawa o sądach ziemiańskich (VL, t. IX, s. $370 \mathrm{i}$ n.) oraz uchwalonego 21 I 1792 r. prawa o sądach trybunalskich (VL, t. IX, s. 381 i n.). Z powyższych uwag można wnosić, iż zapewne Projekt ad codicem iudiciarium powstal przed 10 I $1792 \mathrm{r}$.

${ }^{34}$ Urzędnicy województwa..., s. 76 i 213, oraz por. K. Estreicher, Bibliagrafia polska, L. XXIX, Kraków 1933, s. 321-322.

is VL, t. IX, s. 227-228. Patrz także Ksiega protokolów posiedzeń deputacji do konstytucji wyznaczonej od 4 I $1791 \mathrm{r}$. do $17 \mathrm{~V} 1792 \mathrm{r}$. - zbiory Biblioteki Czartoryskich w Krakowie, sygn. 1705.

${ }^{36}$ Brak tylułu w $\S 22$, a fragment opatrzony nagłówkiem Bekarci nie posiada numeracji. Po $\$ 51$ Roty przysiag znajduja się przykłady $\mathrm{m}$. in. formy pozwu, odpowiedzi czy wyrokowania.

"W swym podziale oraz objęciu regulacją poszczególnych materii projekt Olszowskiego najbardziej zbliżony jest do propozycji Józefa Morawskiego zawartych w Myślach do 
6. Problematyce opieki poświęcił Wojciech Olszowski głównie $\S 32$ zatytulowany $O$ opiekunach i skladający się $\mathrm{z}$ dwunastu punktów ${ }^{38}$.

Opiece miały obligatoryjnie podlegać małoletnie ${ }^{39}$ sieroty do 18 . roku życia oraz wdowy mające dzieci. Wdowy bezdzietne nie musiały mieć opiekuna i mogly rozporządzać własnym majątkiem wedlug swojego uznania ${ }^{40}$. W. Olszowski przyjął więc dla nich rozwiązanie, które przewidywała Rezolucja Rady Nieustającej z 2 stycznia 1778 r. odnośnie do kobiet będących w separacji i rozwiedzionych. Bezdzietne i nie posiadające majątku męża nie podlegały obowiązkowi opieki (jeżeli tego same żąać nie beqda $)^{41}$.

Projekt przewidywal dwa sposoby powołania do opieki. Pierwszeństwo prospekt przyznawal tzw. opiece ojcowskiej - opiekę miała sprawować osoba wyznaczona przez ojca $w$ testamencie. Drugi sposób, zwany w literaturze opieką urzędową lub przydaną, polegał na wyznaczaniu opiekuna przez sąd ${ }^{42}$. W. Olszowski zaproponowal, aby opiekuna dla sierot wskazywal sąd ziemiański wlaściwego powiatu. Brak odpowiedniego wniosku w ciągu dwunastu tygodni od śmierci ojca, skutkować miał wyznaczeniem przez sąd opiekunów z własnej inicjatywy. Projekt milczy, kto miał prawo wniosek taki składać; mogli to zapewne czynić krewni. Małoletni nie mieli zdolności do czynności prawnych, nie mogli więc skutecznie składać wniosków do sądu o przyznanie opiekuna ${ }^{43}$.

prospektu kodeksu, a przedstawionych na sesji III deputacji 24 IX 1791 r. (S. B or owski, Kodeks..., s. 56-63).

${ }^{38}$ Projekt ad codicem..., s. $71-72$.

${ }^{39}$ Termin ,małoletni” funkcjonuje w projekcie na oznaczenie osoby do 24 . roku życia, nie zaś mającej ukończone 18 lat, czy też osoby podlegającej opiece. Swiadczy o tym $\$ 26 \mathrm{pkt}$ 17 - Maloletniość w wszystkich czynnościach nie mieć lat 18, a od zawierania wieczystych transakcji $i$ alienowania nieruchomej fortuny lat 24. Odnośnie do terminów "opieka" i „małoletni” patrz B. Lesińs ki, Konstytucja sejmowa z 1768 roku o opiece $i$ zdolności do czynności prawnych, [w:] Dawne prawo i myśl prawna, red J. Malec i W. Uruszczak, Kraków 1995, s. 232-233 (przyp. 26) oraz E. Kowalsk a, Terminologia opieki nad matoletnimi, Acta Uniwersitatis Lodziensis 1977, S. I: Nauki Humanistyczno-Społeczne, z. 19, s. $43-53$.

40 Stanowił o tym $\$ 29$ pkt 13 - Projekt ad codicem iudiciarium, s. 66.

"Rezolucja nr 13 z 2 I 1778 r. - Zbiór Rezolucji Rady Nieustajacej potrzebnych do wiadomości jurysdykcji squdowych $i$ obywateli Obojga Narodów od Sejmu 1776 do Sejmu 1782 roku zebrany, Warszawa 1785, s. 116-117. Patrz także J. L o ho-S o bolews ki, Prawo opiekuńcze $w$ dawnej Litwie, Lwów 1937, s. 153, jednak błędnie interpretujący ową Rezolucję; w miejscu bowiem, gdzie przecinek rozdzielającego słowa bezdzietne oraz żadnej substancji mężowskiej nie posiadajqce wstawił „1ub”, chociaż chodzi o koniunkcję.

${ }_{42}$ P. Dąbkowski, Prawo..., s. 496-498; J. Loho-Sobolewski, Prawo..., s. 50-53.

${ }^{43}$ Porównaj uwagi odnośnie do tzw. opieki samowładnej-B. Lesińs k i, O tak zwanej opiece samowladnej iv dawnym prawie polskim, Acta Universitatis Nicolai Copernici 1990, Nauki Humanistyczno-Spoleczne, Prawo XXX, z. 218, s. 100 i 112. 
Wdowy natomiast musiały złożyć w ciągu dwunastu tygodni wniosek o przyznanie im przez sąd ziemiański opiekuna, pod rygorem utraty dożywocia ${ }^{44}$.

Wśród wymogów stawianych opiekunom urzędowym - tak dla sierot, jak i wdów - projekt wskazywał na trzy przesłanki: (1) obywatelstwo ${ }^{45}$, (2) mający feudalny charakter wymóg osiadłości oraz (3) pokrewieństwo ${ }^{46}$. Jeżeli brak było krewnych, sąd mógł wyznaczyć opiekuna spośród osób obcych. Uznaniu sądu pozostawiał więc W. Olszowski rozstrzygnięcie (wzorem Rezolucji Rady Nieustajacej z 1 maja 1778 r. ${ }^{47}$ ), czy konkretna osoba była zdolna do pełnienia opieki urzędowej ${ }^{48}$.

W przypadku opieki nad sierotami podstawowe obowiązki opiekuna sprowadzać się miały, jak dotychczas, po pierwsze - do troszczenia się o osobę pupila (o wadze, jaką przywiązywał Wojciech Olszowski do tego obowiązku, świadczy § 32, pkt 9: Opiekunowie najszczególniej starać sie maja o przyzwoite wychowanie $i$ ćwiczenie $w$ naukach maloletnich opiece swojej podleglych, czego gdyby zaniedbali od opieki odpadać powinni), po drugie - do zarządu jego majątkiem ${ }^{49}$. Wśród ograniczeń opiekunów w tym zakresie projekt przewidywal zakaz zaciągania długów na dobrach pupila, $\mathrm{z}$ wyjątkiem sytuacji, gdy należało spłacić długi zaciągnięte przez ojca maloletniego ${ }^{\text {so }}$.

Opiekunowie zobowiązani zostali do dbania o zachowanie $w$ całości dóbr sierot $i$ wdów, za wszelkie działania na ich szkodę ponosili od-

${ }^{44}$ Odnośnie do stanowiska majątkowego i osobistego wdowy w wiekach średnich patrz: B. Lesiński, Stanowisko kobiety $w$ polskim prawie ziemskim do polowy XV wieku, Wrocław 1956, s. 110-134, oraz S. R o m a n, Stanowisko majqtkowe wdowy w średniowiecznym prawie polskim, CPH 1953, t. V, s. 80-108.

45 Na wymóg obywatelstwa nazywanego przynależnósią zwrócił uwagę J. L o h o - S o b ole w ski, Prawo..., s. 58-59. Użyty przez niego termin dowód obywatelstwa skrytykował w recenzji tej pracy J. Adamus, Roczniki Dziejów Społecznych i Gospodarczych [Lwów] 1938, t. VII, s. 434.

${ }^{46}$ Projekt nic nie wspomina o wymogach, jakie powinni spełniać opiekunowie wyznaczeni przez ojca.

${ }^{47}$ Rezolucja $\mathrm{nr} 132$ z 1 V 1778 r. - Zbiór..., s. 117-118.

${ }^{48}$ Chociaż brak w projekcie wyraźnych uregulowań odnośnie do innych wymogów stawianych opiekunom, zapewne zdolność do bycia opiekunem związana była z osiągnięciem odpowiedniego wieku (co najmniej 24 lat) i z przynależnością do stanu szlacheckiego.

${ }^{49}$ Zarówno opieka nad sierotami, jak i wdowami (po 1775 r). miała charakter prawno-familijny (patrz: recenzja pracy J. Loho-Sobolewskiego napisana przez J. B a rd a ch a, Wiadomości Studium Historii Prawa Litewskiego Uniwersytetu Stefana Batorego [Wilno] 1938, 1. I, s. 379.) Cechą odróżniającą opiekę nad wdowami od opieki nad sierotami było to, iż ta pierwsza dotyczyła wyłącznie władzy rozporządzania majątkiem $i$ reprezentacji $w$ sądzie. Patrz: P. Burzyński, Prawo polskie prywatne, t. II, Kraków 1871, s. 219.

${ }^{50}$ Podobnie uregulowana została sytuacja wdów odnośnie do długów przez męża zaciągniętych - 26 , pkt 3 Projektu. 
powiedzialność majątkowa ${ }^{51}$. Chç̨c dodatkowo zabezpieczyć interesy sierot, Wojciech Olszowski zamieścił wśród przepisów klauzulę nieważności wszystkich czynności, które spowodowałyby straty w majątku pupila. W $\S 43$ zatytulowanym Pokrzywdzenie osoby dozwala jednak projektodawca zaspokoić się opiekunowi $\mathrm{z}$ majątku pupila, gdy ten wyrządził jemu szkodę

Dodatkowym obowiązkiem ciążącym na opiekunach był przewidziany w projekcie nakaz składania corocznych sprawozdań z wydatków i dochodów do akt ziemiańskich ${ }^{53}$. Wychodząc spod opieki, pupil mógł zobowiązać opiekuna do zaprzysiężenia rzetelności przedstawianych rejestrów.

Opiekunowie w miejsce rodziców, w przypadku urodzenia dziecka przez pannę podlegającą ich opiece, mieli ustalić osobę ojca celem uzyskania od niego na drodze sądowej części majątku dla dziecka ${ }^{54}$.

$\mathrm{Za}$ sprawowanie opieki opiekun mial otrzymywać wynagrodzenie w wysokości dziesiątej części dochodu ${ }^{55}$. W przypadku zabójstwa sieroty przez inną osobę opiekunom miała przysługiwać glówszczyzna, nazywana w projekcie karq pieniężna, w wysokości 2 tys. złotych polskich ${ }^{56}$.

Wśród sposobów zakończenia opieki, obok dojścia do lat 18, przewidywal projekt zgaśnięcie opieki w wyniku wyjścia panny za mąż. W. Olszowski przyjął rozwiązanie, iż opiekunowie nie powinni przeszkadzać zamążpójściu, a brak ich zgody nie pociągal za sobą niekorzystnych skutków majątkowych. Opiekunowie w takich wypadkach mieli bowiem obowiązek przekazać, wychodzącej spod opieki małoletniej, cały majątek pozostały po jej rodzicach.

Odpadniecie od opieki przewidywal projekt w trzech wypadkach: braku należytej troski opiekuna względem wychowania i wyksztalcenia pupila, nieskładania corocznych sprawozdań do akt ziemiańskich oraz naruszenia obowiązku zachowania w calości dóbr sierot lub wdów.

Wraz z zakończeniem opieki opiekunowie zobowiązani byli przekazać byłemu pupilowi cały majątek, tj.: ruchomości i nieruchomości, listy, inwentarze, pieniądze i wszystkie inne rzeczy, które pozostały po rodzicach.

\footnotetext{
${ }^{\$ 1}$ Właśnie wymóg osiadłości opiekuna miał być rękojmią jego możliwości odpowiedzialności majątkowej.

${ }^{52}$ Przepis ten dotyczy także stosunków pomiędzy kuratorem a osobą pomieszanych zmyslów.

${ }^{3}$ Podobnie postanawiała konstytucja z $1775 \mathrm{r}$. Ubezpieczenie sierot $i$ wdów, nakładając - odmiennie niż projekt Olszowskiego - obowiązek rocznych sprawozdań wyłącznie na opiekunów urzędowych; VL, t. VIII, s. 113.

${ }_{54}$ Obowiązek ten umieszczony w tytule Bękarci bez paragrafu, pkt 5, s. 106 Projektu.

ss Odmiennie w projekcie ks. A. Reptowskiego, gdzie mowa jest o dziesiątej części czystej intraty, a więc dochodu po potrąceniu wszystkich wydatków.

${ }^{56}$ Projekt \& 46, pkt 45, s. 104.
} 
Małoletni nie mógł jednak sprzedać tego majątku, dopóki nie osiągnął wieku pełnoletności - 24 lat $^{57}$.

W projekcie brakuje postanowień w odniesieniu do liczby opiekunów i ich wzajemnej relacji, wyraźnych przepisów dotyczących funkcji sądowych oraz postanowień odnośnie do sporządzania inwentarza dóbr sierot w momencie obejmowania opieki ${ }^{58}$.

7. Przy ocenie regulacji opieki w Projekcie ad codicem iudiciarium należy mieć na uwadze fakt, iż Wojciech Olszowski podjąl próbę napisania całego kodeksu, kładąc nacisk głównie na procedurę i organizację sądownictwa. Nie było więc możliwe szczegółowe opisanie poszczególnych instytucji. Pomimo zachowania zwięzłości w konstrukcji przepisów, dzieło jego liczylo w druku 141 stron. Chociaż przepisy o opiece w projekcie Olszowskiego wykazują pewne braki, to samo ich umieszczenie w projekcie jest wyrazem ogólnej opinii szlachty o wadze tej instytucji.

Przepisów o opiece nie uznamy za nadzwyczaj reformatorskie, jednak pewne uregulowania wskazują na nowoczesne ujmowanie tej instytucji przez autora. W szczególności chodzi o rolę, jaką miały odgrywać w tym zakresie nowo utworzone sądy ziemiańskie (powoływanie opiekunów na wniosek, w ostateczności zaś z własnej inicjatywy; ocena zdolności bycia opiekunem; sprawowanie nadzoru nad skladaniem przez opiekuna do akt ziemiańskich sprawozdań majątkowych). Ponadto zasadą przy pelnieniu opieki miało być kierowanie się przez opiekuna dobrem pupila, a więc troską nie tylko o majątek, ale także wykształcenie i wychowanie. Odnośnie do powolywania opiekunów Olszowski zaproponował tylko dwa sposoby, nie uznając za wlaściwe wprowadzenie tzw. opieki naturalnej (przyrodzonej), czyli sprawowanej przez krewnych sieroty $\mathrm{z}$ racji samego stosunku pokrewieństwa. Skonstatować należy, iż opieka traci swój prywatny i wyłącznie rodzinny charakter $^{59}$.

Gdyby prace nad prospektem (według którego pisane mialy być projekty konkursowe) zakończone zostały przez deputację kodyfikacyjną, to w zakresie opieki W. Olszowski z pewnością opierałby się na propozycjach zgłoszonych przez ks. A. Reptowskiego w Myślach o opiekach wszelkiego rodzaju ${ }^{60}$.

\footnotetext{
${ }^{57}$ Model przejęty z konstytucji sejmowej 1768 r., pairz: B. Le siń ski, Konstytucja.., s. 232-233.

${ }^{38}$ Projekt przewidywał obowiązek spisania inwentarza jedynie w związku z prawem dożywocia wdów, nie zaś opieki (taki regestr sporządzać miała wdowa w obecności jednego lub dwóch przyjaciół i podać go do Akt ziemiańskich w ciągu roku od śmierci męża, pod rygorem utraty dożywocia; § 29, pkt 7 Projektu).

${ }^{59}$ Por. uwagi o opiece w Zbiorze Praw Sądowych - E. B ork owska-Bagieńska, Zbiór..., s. $181-185$.

${ }^{50}$ Deputacja właśnie ks. A. Reptowskiemu zleciła opracowanie tej części prospektu, co też uczynil, czytając swoje Myśli na sesji 7 I 1792 r.
} 
Analiza porównawcza Myśli oraz postanowień o opiece nad małoletnimi w Projekcie ad codicem iudiciarium prowadzi do wniosku, iż W. Olszowski w znacznej mierze wypełniłby zalecenie deputacji o pisaniu projektu konkursowego, zgodnie $\mathrm{z}$ wytycznymi prospektu. Spośród dziesięciu zasad do opieki ks. A. Reptowskiego, w projekcie Olszowskiego odnaleźć można (choć z pewnymi modyfikacjami) dziewięćć ${ }^{61}$. Odmiennie określił W. Olszowski sytuację prawną wdów, poddając część $z$ nich opiece, nie zaś jak proponowal ks. A. Reptowski - kurateli.

i) Brak postanowień odnośnie do liczby opiekunów i ich wzajemnego stosunku (S. B o r ow s k i, Kodeks.., s. 140-147). 